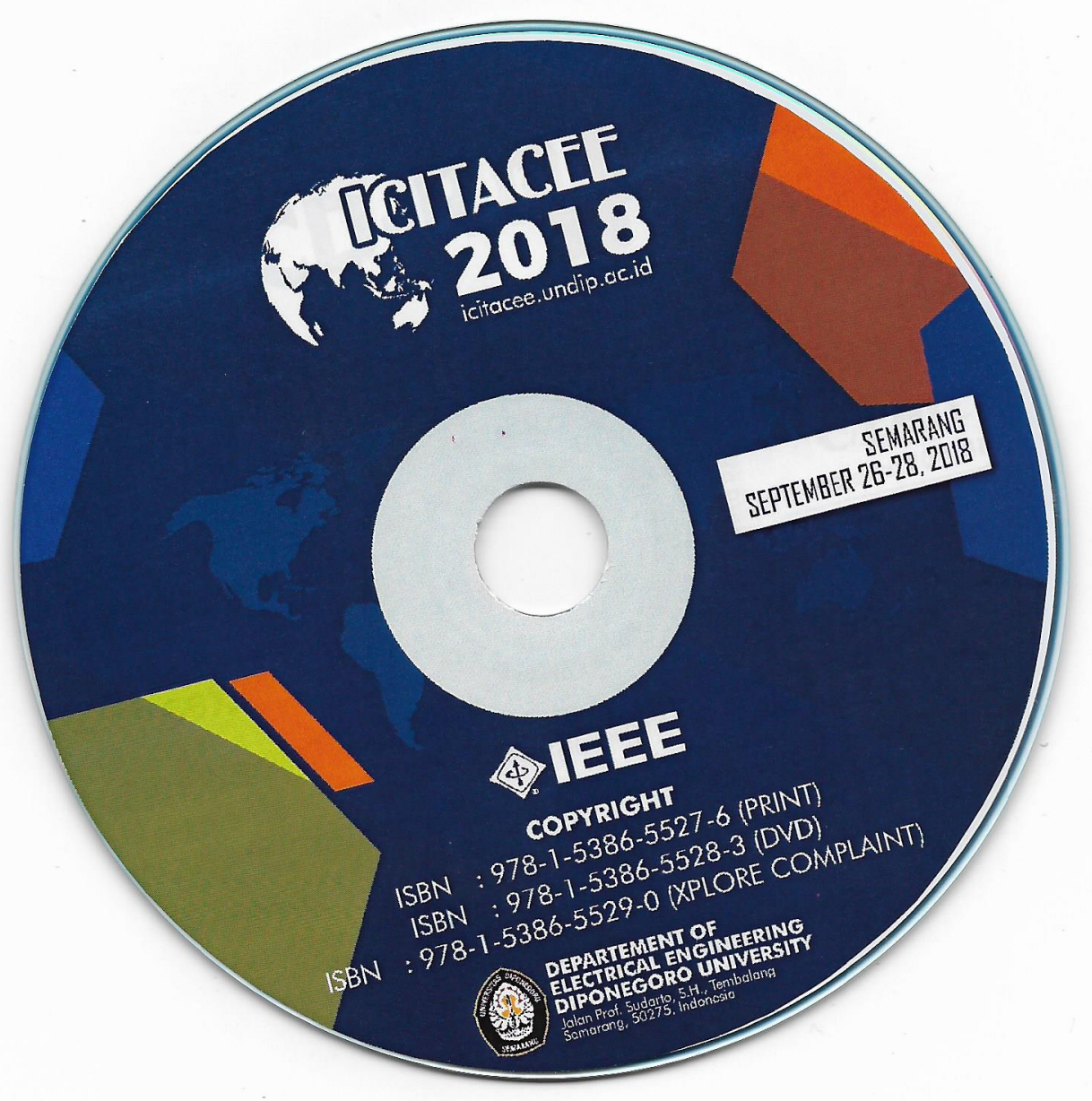




\section{ICITACEE 2018}

Semarang, Indonesia, September $26^{\text {th }}-28^{\text {th }}, 2018$

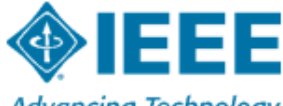

Advancing Technology for Humanity

Home Program ToC TPC Committees Authors Reviewers

Homepage

The conference entitled "The 2018 5th International Conference on Information Technology, Computer, and Electrical Engineering (ICITACEE 2018)" provides a forum for researchers, academicians, professionals, and students from various engineering fields and with cross-disciplinary working or interested in the development and design of information technology, computer system, and electrical engineering to interact and disseminate the latest issues and researches. It also offers opportunity to enjoy the heritage and the beauty of Semarang.

ICITACEE is an annual conference organized between Electrical Engineering Department and Computer Engineering Department and in 2018 this conference will be organized by Electrical Engineering Department.

The theme of ICITACEE 2018 is "Green Technology and Smart Environment for a Connected World". The conference covers the topics but not limited to information technology, information systems, power systems, signal processing, electronics, micro-electronics, biomedical engineering, and communication systems as well as other field that corresponds, such as intelligent systems, intelligent transportation applications, health care applications, and environmental protection. ICITACEE 2018 invites the scholars and encourages the researchers to submit high quality manuscripts and papers to this conference.

The papers accepted and presented will be forwarding for consideration to be published in the IEEE Xplore Digital Library.

ICITACEF 2018 5th I nternational Conference on Information Technology, Computer and Electrical Engineering (I CITACEE) took place 26-28 September, 2018 in Semarang, Indonesia.

$\begin{array}{ll}\text { IEEE catalog number: } & 978-1-5386-5529-0 \\ \text { ISBN: } & 978-1-5386-5528-3\end{array}$

Copyright and Reprint Permission: Abstracting is permitted with credit to the source. Libraries are permitted to photocopy beyond the limit of U.S. copyright law for private use of patrons those articles in this volume that carry a code at the bottom of the first page, provided the per-copy fee indicated in the code is paid through Copyright Clearance Center, 222 Rosewood Drive, Danvers, MA 01923. For other copying, reprint or republication permission, write to IEEE Copyrights Manager, IEEE Operations Center, 445 Hoes Lane, Piscataway, NJ 08854. All rights reserved. Copyright @ 2018 by IEEE.

Organized by Department of Electrical Engineering Diponegoro University Prepared by EDAS Conference Services.

Contact (c) Copyright 2018 IEEE - All Rights Reserved. 


\section{Home Program ToC TPC Committees Authors Reviewers}

Technical Program Committee

$\begin{array}{lll}\text { Mochammad Facta } & \text { Diponegoro University } & \text { Indonesia } \\ \text { Masayuki Kurosaki } & \text { Kyushu University } & \text { Japan } \\ \text { Trio Adiono } & \text { Bandung Institute of Technology } & \text { Indonesia } \\ \text { P. Insap Santosa } & \text { Gadjah Mada University } & \text { Indonesia } \\ \text { Mauridhi Heri Purnomo } & \text { Sepuluh Nopember Institute of Technology } & \text { Indonesia } \\ \text { Khoirul Anwar } & \text { Telkom University } & \text { Japan } \\ \text { Wahyudi } & \text { Diponegoro University } & \text { Indonesia } \\ \text { Wahyul Amien Syafei } & \text { Diponegoro University } & \text { Indonesia } \\ \text { Munawar Agus Riyadi } & \text { Diponegoro University } & \text { Indonesia } \\ \text { Sidiq Syamsul Hidayat } & \text { Semarang State Polytechnics } & \text { Indonesia } \\ \text { Supari } & \text { Semarang University } & \text { Indonesia } \\ \text { Slamet Riyadi } & \text { Soegijapranoto Katholic University } & \text { Indonesia } \\ \text { Achmad Arifin } & \text { Sepuluh Nopember Institute of Technology } & \text { Indonesia } \\ \text { M. Hadin } & \text { Sultan Agung Islamic University } & \text { Indonesia } \\ \text { Onil Nazra Persada } & \text { CEA } & \text { France } \\ \text { Taufik } & \text { California Polytechnic State University } & \text { USA } \\ \text { Aris Triwiyatno } & \text { Diponegoro University } & \text { Indonesia } \\ \text { Pandu Sandi Pratama } & \text { Pusan National University } & \text { South Korea } \\ \text { Oky Dwi Nurhayati } & \text { Diponegoro University } & \text { Indonesia }\end{array}$

Organized by Department of Electrical Engineering Diponegoro University Prepared by EDAS Conference Services.

Contact (c) Copyright 2018 IEEE - All Rights Reserved. 
CITACEE The $5^{\text {th }}$ International Conference on Information Technology,

Computer and Electrical Engineering

ICITACEE 2018

Semarang, Indonesia, September $26^{\text {th }}-28^{\text {th }}, 2018$

Home Program ToC TPC Committees Authors Reviewers

Committees

Steering Committee

Hermawan (Diponegoro University, Indonesia)

Mauridhi Hery Purnomo (Institut Teknologi Sepuluh Nopember, Indonesia)

Fitri Yuli Zulkifli (Universitas Indonesia, Indonesia)

Dade Nurjanah (Telkom University, Indonesia)

Razali Ngah (Universiti Teknologi Malaysia, Malaysia)

\section{Conference Committee}

\section{General Chair}

Aghus Sofwan (Diponegoro University)

\section{General Co-Chair}

Kurniawan Teguh Martono (Diponegoro University)

\section{Secretariat Chair}

M. Arfan ( Universitas Diponegoro)

\section{Organizing Committee}

Abdul Syakur

Munawar Agus Riyadi

Trias Andromeda

I wan Setiawan

Achmad Hidayatno

Ajub Ajulian Zahra

Yosua Alvin Sutrisno

Eko Handoyo

Sukiswo

Yuli Christyono

Organized by Department of Electrical Engineering Diponegoro University Prepared by EDAS Conference Services.

Contact O Copyright 2018 IEEE - All Rights Reserved. 


\section{The $5^{\text {th }}$ International Conference on Information Technology, Computer and Electrical Engineering}

\section{ICITACEE 2018}

Semarang, Indonesia, September $26^{\text {th }}-28^{\text {th }}, 2018$

\section{Reviewers}

Mohd Helmy Abd Wahab Hanung Adi Nugroho Widyawardana Adiprawita Hadha Afrisal Muhammad Anshari

Zainal Arif

Dhany Arifianto

Rosa Asmara

I Gede Puja Astawa

Nazrulazhar Bahaman

Yoanes Bandung

Achmad Basuki

Ruri Basuk

Saiful Bukhori

Elin Cahyaningsih

Harishchandra Dubey

Fahmi Fahmi

Soni Fajar Surya Gumilang

Susatyo Handoko

Eko Handoyo

Triwahju Hardianto

Fajar Hardoyono

Fakhriy Hario

Zulfatman Has

Dwiana Hendrawati

Hermawan Hermawan

Darlis Herumurti

Achmad Hidayanto

Achmad Hidayatno

Hindarto Hindarto, Dr

Paulus Insap Santosa

Muhamad Syamsu Iqbal

Lie Jasa

Arman Jaya

Endra J oelianto

Prima Kristalina

Julianto Lemantara

Kurniawan Martono

Norshita Mat Nayan

Rizal Munadi

Arif Muntasa

Imamul Muttakin

Haniza Nahar

Kartiko Nugroho

Lukito Edi Nugroho

Prapto Nugroho

Oky Nurhayati

Agung Prasetijo

Ardyono Priyad

Mauridhi Hery Purnomo

Muhammad Rivai

Slamet Riyad

Siti Rochimah

Azmi Saleh

Ali Samoud

Imam Santoso

Riyanarto Sarno

I Nyoman Wahyu Satiawan

Haikal Satria

Dian Sawitri

Eko Sediyono

Siti Sendari

Florentinus Setiawan

wan Setiawan

Noor Ahmad Setiawan

Eko Setijadi

Budi Setiyanto

Arief Setyanto

Indrazno Siradjuddin

Simon Siregar
Universiti Tun Hussein Onn Malaysia

Universitas Gadjah Mada

Institut Teknologi Bandung

King's College London

Universiti Brunei Darussalam

Politeknik Elektronika Negeri Surabaya

Institut Teknologi Sepuluh Nopember

Politeknik Negeri Malang

Politeknik Elektronika Negeri Surabaya

Univeristi Teknikal Malaysia Melaka

Institut Teknologi Bandung

Politeknik Elektronika Negeri Surabya

University of Dian Nuswantoro

Universitas J ember

University of Indonesia

University of Texas at Dallas

University of Sumatera Utara

elkom University

Universitas Diponegoro

Diponegoro University

University of J ember

Universitas Gadjah Mada

Brawijaya University

University of Muhammadiyah Malang

Institut Teknologi Sepuluh Nopember

Diponegoro University

Institut Teknologi Sepuluh Nopember

University of Indonesia

Diponegoro University

University Muhammadiyah Of Sidoarjo

Universitas Gadjah Mada

Universitas Mataram

Udayana University

Electronics Engineering Polytechnic Institute of Surabaya

Institut Teknologi Bandung

Politeknik Elektronika Negeri Surabaya (PENS)

Institut Bisnis dan Informatika Stikom Surabaya

Diponegoro University

National University of Malaysia

Syiah Kuala University

Trunojoyo University

CTECH Labs Edwar Technology Co.

Universiti Teknikal Malaysia

Universiti Teknologi Malaysia

Universitas Gadjah Mada

Universitas Gadjah Mada

Diponegoro University

Universitas Diponegoro

ITS

Institut of Technology Sepuluh Nopember

Institut Teknologi Sepuluh Nopember

Soegijapranata Catholic University

Institut Teknologi Sepuluh Nopember

Jember University

Science

University of Diponegoro

Institut Teknologi Sepuluh Nopember

Mataram University - West Nusa Tenggara

Universiti Teknologi Malaysia

UDINUS

Satyawacana Christian University

Universitas Negeri Malang

Soegijapranata Catholic University

Universitas Diponegoro

UGM

Institut Teknologi Sepuluh Nopember

Universitas Gadjah Mada

Universitas AMI KOM Yogyakarta

State Polytechnic of Malang

Telkom University
Malaysia

Indonesia

Indonesia

Indonesia

Brunei Darussalam

Indonesia

Indonesia

Indonesia

Indonesia

Malaysia

Indonesia

Indonesia

Indonesia

Indonesia

Indonesia

USA

Indonesia

Indonesia

Indonesia

Indonesia

Indonesia

Indonesia

Indonesia

Indonesia

Indonesia

Indonesia

Indonesia

Indonesia

Indonesia

Indonesia

Indonesia

Indonesia

Indonesia

Indonesia

Indonesia

Indonesia

Indonesia

Indonesia

Malaysia

Indonesia

Indonesia

Indonesia

Malaysia

Malaysia

Indonesia

Indonesia

Indonesia

Indonesia

Indonesia

Indonesia

Indonesia

Indonesia

Indonesia

Indonesia

Tunisia

Indonesia

Indonesia

Indonesia

Malaysia

Indonesia

Indonesia

Indonesia

Indonesia

Indonesia

Indonesia

Indonesia

Indonesia

Indonesia

Indonesia

Indonesia 
Suharyanto Suharyanto

I. Sukajaya

rrine Sulistiawati

Heri Suryoatmojo

Suryono Suryono, Sr

Wahyul Amien Syafe

Abdul Syakur

Herman Tolle

Aris Triwiyatno

Tsuyoshi Usagawa

Wahyudi Wahyudi

Gunawan Wibisono

Sigit Basuki Wibowo

Danang Wijaya

I Gede Pasek Suta Wijaya

Arbai Yusuf
Gadjah Mada University

Universitas Pendidikan Ganesha, Singaraja

Indonesia

Indonesia

Institut Teknologi Sepuluh Nopember Surabaya Indonesia Indonesia

Institut Teknologi Sepuluh Nopember Indonesia

Diponegoro University

Indonesia

Indonesia

Diponegoro University Indonesia

Universitas Brawijaya

Indonesia

Indonesia

Japan

Indonesia

Indonesia

Ireland

Indonesia

Indonesia

Indonesia

Organized by Department of Electrical Engineering Diponegoro University

Contact @ Copyright 2018 IEEE - All Rights Reserved. 


\section{ICITACEE 2018}

Semarang, Indonesia, September $26^{\text {th }}-28^{\text {th }}, 2018$

Program

Thursday, September 27

Thursday, September 27 9:30 - 11:30

I NV: I nvited Paper

Green Computing: Opportunity of Using Breadth Fixed Gossip Algorithm for Optimizing Power Supply Route in Power Plant Mauridhi Purnomo (Institut Teknologi Sepuluh Nopember, Indonesia) Maurid
pp. $1-6$

Thursday, September 27 13:00 - 15:15

A1: Electronic Circuit \& Control

Magnetic Field Relationship between Distance and I nduced Voltage Generated by EMP Betantya Nugroho and Azli Yahya (Universiti Teknologi Malaysia, Malaysia); Abd Rahim (Mindmatics, Malaysia); Trias Andromeda (Universitas Diponegoro, Indonesia) Diponegorc $7-10$
pp.

Communication Protocol on 64-Channel ECVT Data Acquisition System Arbai Yusuf (Universitas Indonesia \& C-Tech Labs Edwar Technology, Indonesia) Arbai Yusuf
pp. $11-14$

Cooling System Design Based on Thermoelectric Using Fan Motor on-off Contro Munnik Haryanti (Universitas Dirgantara Marsekal Suryadarma, Indonesia) pp. $15-18$

Design of The 3D Surface Scanning System for Human Wrist Contour Using Laser Line I maging Riky Tri Yunardi and Ario Imandiri (Universitas Airlangga, Indonesia) pp. $19-23$

Temperature Controlling Using PID Controller on Rice Grain Fluidized Dryer Prototype Aris Triwiyatno (Diponegoro University, Indonesia)

PID Based Air Heater Controller I mplemented With Matlab/ Simulink and Arduino Uno Bambang Supriyo, Dadi Dadi, Sulistyo Warjono, Adi Wisaksono, Sri Astuti and Kusno Utomo (Politeknik Negeri Semarang, Indonesia) pp. 28-32

Design A Low Cost Wind Direction Sensor With High Accuracy Yoga Utama (University of Widya Kartika, Indonesia) pp. $33-38$

Quadruped Robot with Stabilization Algorithm on Uneven Floor using 6 DOF I MU based Inverse Kinematic Rofiq Prayogo (Diponegoro University, Indonesia) pp. $39-44$

Design and Characterization of Low-Cost Soft Pneumatic Bending Actuator for Hand Rehabilitation Mochammad Ariyanto, Joga Setiawan, Rifky Ismail, Ismoyo Haryanto, Tania Febrina and Doni Saksono (Diponegoro University, Indonesia) pp. $45-50$

B1: Electric \& Power System 
Design and Performance Test of Three Phased SRF-PLL using DSPIC30F4011 Syarief Ali, I wan Setiawan and Susatyo Handoko (Universitas Diponegoro, Indonesia) pp. $51-56$

The Effect of Excitation Capacitors on Induction Generators in Loss-of-Grid Events Mokhammad Isnaeni Bambang Setyonegoro (Universitas Gadjah Mada, Indonesia); Danang Wijaya (UGM, Indonesia); Eka Firmansyah (Universitas Gadjah Mada, Indonesia)

pp. $57-60$

Transient Stability Study in Grid I ntegrated Wind Farm Samuel Adi Kusumo (Universitas Gadjah Mada, Indonesia); Lesnanto Multa Putranto (UGM, Indonesia); Tiyono Tiyono (Universitas Gadjah Mada, Indonesia)

Analysis of Energy Potential of Biomass Electricity from Leaf Waste by Using Briquette Method Herlina Wahab (Sriwijaya University \& University of Indonesia, Indonesia); Rudy Setiabudy (Universitas Indonesia (UI), Indonesia); Akbar Cahyadi (Universitas Indonesia, Indonesia)

pp. $67-72$

DVR to Voltage Sag Mitigation Due to Induction Motor Starting and 3 Phase Fault Muhammad Kuncoro and I wa Garniwa (University of Indonesia, Indonesia) pp. $73-78$

A Single Phase 11-Level Inverter for Photovoltaic Application Wira Adhitama (Soegijapranata Catholic University, Indonesia) pp. $79-83$

Design and I mplementation of I nverter Single Phase Nine-Level Using PI C18F4550 Natanael Novalutfi (Soegijapranata Catholic University, Indonesia) pp. $84-88$

Energy Saving Measures and Potential of Energy Efficiency at The University of Surabaya Fitri Kartikasari (University of Surabaya, Indonesia); Elieser Tarigan (University of Surabaya \& Electrical Engineering, Indonesia); Yunus Fransiscus and Tuani Lidyawati (University of Surabaya, Indonesia)
pp. $89-92$

Design and Simulation of an Asymmetrical 11-Level Inverter for Photovoltaic Applications Christopher Tjokro and Leonardus Pratomo (Soegijapranata Catholic University, Indonesia) pp. 93-98

\section{C1: Information \& Computer Technologies}

MRI I mage Segmentation using Morphological Enhancement and Noise Removal based on Fuzzy C-means Robert Setyawan, Mustofa Alisahid Almahfud, Christy Atika Sari, De Rosal Ignatius Moses Setiadi and Eko Hari Rachmawanto (Dian Nuswantoro University, Indonesia) pp. 99-104

Measurement on Real-Time Diagnostic of Gastric Tumor Model Using Wireless Endoscopy System Novietasari Chisnariandini (University of Indonesia, Indonesia); Arie Pangesti Aji (Universitas Indonesia, Indonesia); Yudiansyah Yudiansyah (University of Indonesia, Indonesia); Prita Dewi Mariyam, Jauharul Fuadi, Yulianto La Elo and Basari Basari (Universitas Indonesia, Indonesia)
pp. 105-108

Relational Database Structure and Operations Engineering Based on UML Diagram Lukman Hakim (Bandung Institute of Technology, Indonesia); Sukrisno Mardiyanto (Institut Teknologi Bandung, Indonesia) pp. 109-113

Design of Secure I oT Platform For Smart Home System Arvandy Arvandy and Yoanes Bandung (Institut Teknologi Bandung, Indonesia)
pp. 114-119

Marker I mage Variables Measurement of Augmented Reality in Mobile Application I ke Windasari, Yudi Windarto and Risma Septiana (Diponegoro University, Indonesia) pp. $120-124$

Sentiment Analysis and Topic Modelling for I dentification of Government Service Satisfaction Moh Nasrul Aziz, Ari Firmanto, Ahmad Miftah Fajrin and R. V. Hari Ginardi (Institut Teknologi Sepuluh Nopember, Indonesia)
pp. 125-130

Prototype of Online Examination on MoLearn Applications Using Text Similarity to Detect Plagiarism J ulianto Lemantara (Institut Bisnis dan Informatika Stikom Surabaya, Indonesia); Dewiyani Sunarto (Institute of Business and Informatic Stikom Surabaya, Indonesia); Bambang Hariadi, Tri Sagirani and Tan Amelia (Institut Bisnis dan Informatika Stikom Surabaya, Indonesia)
pp. 131-136

Performance Comparison Between AES256-Blowfish and Blowfish-AES256 Combination Muhammad Muin (Universitas AMI KOM Yogyakarta \& STMIK Bina Patria, Indonesia); Arief Setyanto (Universitas AMIKOM Yogyakarta, Indonesia); Sudarmawan Sudarmawan (AMI KOM Yogyakarta University, Indonesia); Kartika Santoso (STMIK Bina Patria, Indonesia) pp. 137-141

A Natural Childbirth Training Simulation in Virtual Environment For Prospective Midwife Alvin Nugraha, Aulia Faza, Wulan Indayani and Hanny Haryanto (Universitas Dian Nuswantoro, Indonesia); Abas Setiawan (Dian Nuswantoro University, Indonesia) pp. $142-146$

\section{D1: Telecommunications \& Radio Frequency}

Study on 2G Termination in Indonesia using BCG Matrix Alaind Fadrian and Ajib S. Arifin (Universitas Indonesia, Indonesia)
pp. 147-151

Performance of 8FSK base on PACTOR I protocol over AWGN channels Mohd Yazid Ab Razak (National University of Malaysia \& Mindmatics Sdn Bhd, Malaysia); Abd Rahim Mat Sidek (Mindmatics Sdn Bhd, Malaysia); Nasharuddin Zainal (Universiti Kebangsaan Malaysia, Malaysia) pp. $152-156$

Development of Radio Direction Finder using 6 Log Periodic Dipole Array Antennas Kartiko Nugroho, Azli Yahya and Nor Hisham Khamis (Universiti Teknologi Malaysia, Malaysia); Nuramirah Mohd Nor (Mindmatics Sdn. Bhd., Malaysia); Abd Rahim (Mindmatics, Malaysia); Mohammad Razman Shaari (Mindmatics Sdn. Bhd., Malaysia) pp. 157-160

Directional 2×2 MI MO Microstrip Antenna Design and Optimization for LTE Band-3 Application Tommi Hariyadi and Rizky Megantara (Universitas Pendidikan Indonesia, Indonesia) pp. $161-166$

High Throughput Wireless Printer Server Based on IEEE 802.11n Wahyul Amien Syafei (Diponegoro University, Semarang \& Kyushu Institute of Technology, I izuka, Indonesia); Imam Santoso (Diponegoro University, Indonesia)
pp. $167-170$

Analysis on Batik Water Waste Monitoring System based on LoRa Communication Michael Stephen Moses Pakpahan, Eko Didik Widianto and Risma Septiana (Diponegoro University, Indonesia) pp. 171-175 
A GIS-based Waste Water Monitoring System Using LoRa Technology

Yudi Windarto and Agung Prasetijo (Diponegoro University, Indonesia); Galang Damara (Universitas Diponegoro, Indonesia)
pp. 176-179

Filtering for Data Aquisition on Wireless Sensor Network

Aghus Sofwan, Sumardi Sumardi and Nely Ulwiyati (Diponegoro University, Indonesia)

pp. $180-184$

Thursday, September 27 15:30 - 17:30

\section{A2: Electronic Circuit \& Control}

Predictive Control for Relative Performance Management Dharma Aryani (State Polytechnic of Ujung Pandang, Indonesia); Nur Asyik Hidayatullah (State Polytechnic of Madiun, Indonesia)
pp. 185-190

Design and Development of I njection Current Control On I nverter-Based Proportional Resonant Method Abdul Haris Kuspranoto (Universitas Diponegoro, Indonesia)
pp. 191-196

Development of Object Tracking System Using Remotely Operated Vehicle Based on Visual sensor Erwin Saputra and Ronny Mardiyanto (Institut Teknologi Sepuluh Nopember, Indonesia)

Predictive Control Approach for Restricted Areas Avoidance of Autonomous System Sutrisno Sutrisno, Widowati Widowati, Sunarsih Sunarsih and Kartono Kartono (Diponegoro University, Indonesia)
pp. 203-207

Kufarm: A Modified Platform of Automation Planting System Damar Pramuditya (Telkomuniversity, Indonesia); Agung Nugroho J ati and Fairuz Azmi (Telkom University, Indonesia) pp. 208-213

Tracking Object based on GPS and I MU Sensor Wahyudi Wahyudi (Department of Electrical Engineering, Diponegoro University)

Development of Navigation Method of Buoyant Boat for Maintaining Position of The Boat and Rov Ronny Mardiyanto, Heri Suryoatmojo and Badrut Tamam (Institut Teknologi Sepuluh Nopember, Indonesia) pp. 219-224

Development of a Low-Cost Quadrupedal Starfish Soft Robot Mochammad Ariyanto, Munadi M and Joga Setiawan (Diponegoro University, Indonesia) pp. $225-229$

Performance I mprovement of Robot Warehouse Based on Battery Operational Conditions Almira Budiyanto, Aris Setiawan and Setyawan Wahyu Pratomo (Universitas Islam Indonesia, Indonesia) pp. $230-233$

\section{B2: Electric \& Power System}

Design of Adaptive PI D Controller for Fuel Utilization In Solid Oxide Fuel Cell Darjat Darjat, Sulistyo Sulistyo and Aris Triwiyatno (Diponegoro University, Indonesia) pp. 234-239

Study on Photovoltaic Hosting in Yogyakarta Electric Distribution Network Faishal Fuad Rahman Soeharto (Universitas Gadjah Mada, Indonesia); Kristianto Adi Widiatmoko and Sarjiya Sarjiya (Gadjah Mada University, Indonesia); Lesnanto Multa Putranto (UGM, Indonesia) pp. $240-244$

Analysis of Grounding System in 150 kV Kudus Substation Riza Pratama (Diponegoro University, Indonesia) pp. $245-250$

Maximum Power Tracking of Solar Panel using Modified I ncremental Conductance Method Trias Andromeda (Universitas Diponegoro, Indonesia); Betantya Nugroho (Universiti Teknologi Malaysia, Malaysia); Susatyo Handoko (Universitas Diponegoro, Indonesia); Azli Yahya (Universiti Teknologi Malaysia, Malaysia); Hermawan Hermawan and Mochammad Facta (Diponegoro University, Indonesia); I wan Setiawan (Universitas Diponegoro, Indonesia) pp. 251-255

Electrical Load Forecasting Study Using Artificial Neural Network Method for Minimizing Blackout Husein Mubarok and Mukhamad Sapanta (Universitas Islam Indonesia, Indonesia) pp. $256-259$

Comparison Study on Leakage Current of 20 kV Silicon Rubber and Epoxy Resin Insulator Under Dry and Wet Condition Taryo Taryo (Diponegoro University, Indonesia); Abdul Syakur (Universitas Diponegoro, Indonesia); Hermawan Hermawan (Diponegoro University, Indonesia)

Leakage Current Characteristics of 20 kV Epoxy Resin Insulators Under Variation Humidity Pertiwi Utami and Hermawan Hermawan (Diponegoro University, Indonesia); Abdul Syakur (Universitas Diponegoro, Indonesia) pp. $264-267$

Measurement System for Surface Leakage Current at Epoxy Resin Insulating Materials Abdul Syakur (Diponegoro University, Indonesia); Wahyudi Wahyudi (Departemen Teknik Elektro UNDIP, Indonesia); Jumrianto J umrianto, Jr (Diponegoro University \& NET TV, Indonesia)

An Investigation of Direct Grounding Effect on Modeling of Lightning and Tower in Transmission Line Agung Nugroho, Omar Abouzeid, Mochammad Facta, Karnoto, Abdul Syakur and Hermawan Hermawan (Diponegoro University, Indonesia) pp. $272-275$

\section{C2: Information \& Computer Technologies}

Halstead Metric for Quality Measurement of Various Version of Statcato I wan Binanto (Sanata Dharma University, Indonesia); Bahtiar Saleh Abbas and Nesti Sianipar (Bina Nusantara University, Indonesia); Harco Leslie Hendric Spits Warnars (Bina Nusantara University \& Doctor of Computer Science, Indonesia) pp. $276-280$

Environmental Health Monitoring with Smartphone Application Kodrat Iman Satoto, Eko Didik Widianto and Sumardi Sumardi (Diponegoro University, Indonesia) pp. $281-286$

Two-Step Ranking Document Using the Ontology-Based Causality Detection A. A. I. N. Eka Karyawati and L. A. A. Rahning Putri (Udayana University, Indonesia)

Knowledge Management Model in Syariah Banking Nurdin Nurdin (Institut Agama Islam Negeri Palu); Sagaf S Pettalongi and Khaeruddin Yusuf (Institut Agama Islam Negeri Palu, Indonesia) pp. 293-298 
The Spreading of Misinformation online: 3D Simulation

Pardis Pourghomi and Milan Dordevic (American University of the Middle East, Kuwait); Fadi Safieddine (Queen Mary University of London, United Kingdom (Great Britain))

pp. 299-304

IT Management Flexibility Concept for Higher Education

Wasilah Wasilah (Gajah Mada University (UGM) \& Informatics and Bisniss Institute (IBI DARMAJAYA) Bandar Lampung, Indonesia); Lukito Edi Nugroho

and Paulus Insap Santosa (Universitas Gadjah Mada, Indonesia)
pp. 305-309

Review on Cost-Value Approach for Requirements Prioritization Techniques

Tan Amelia (Institut Bisnis dan Informatika Stikom Surabaya, Indonesia); Rozlina Mohamed (Universiti Malaysia Pahang, Malaysia)
pp. 310-314

Critical Success Factor of I nformation Technology I mplementation in Supply Chain Management

Erick Fernando and Surjandy Surjandy (Bina Nusantara University, Indonesia); Harco Leslie Hendric Spits Warnars (Bina Nusantara University \& Doctor of Computer Science, Indonesia); Meyliana Meyliana (Bina Nusantara University, Indonesia); Raymond Kosala (Faculty of Computing \& Media, Indonesia); Edi Abdurachman (Bina Nusantara University, Indonesia) pp. $315-319$

The Evaluation of Child's Health Monitoring System Using the Usability Testing Approach Kurniawan Martono (Diponegoro University, Indonesia) pp. $320-324$

\section{D2: Information \& Computer Technologies}

Ticketing Chatbot Service using Serverless NLP Technology Eko Handoyo and M Arfan (Diponegoro University, Indonesia); Yosua Alvin Adi Soetrisno (Diponegoro University \& Faculty of Engineering, Indonesia); Maman Somantri, Aghus Sofwan and Enda Wista Sinuraya (Diponegoro University, Indonesia) pp. $325-330$

Design of Water Quality Control for Shrimp Pond Using Sensor-Cloud I ntegration Maman Somantri, Aghus Sofwan, M Arfan, Vivi Endar Herawati and Hafiidhin Abdurrasyiid (Diponegoro University, Indonesia)
pp. 331-336

A Comparative Study of I mage Cryptographic Method De Rosal I gnatius Moses Setiadi, Eko Hari Rachmawanto and Christy Atika Sari (Dian Nuswantoro University, Indonesia); Ajib Susanto (Universitas Dian Nuswantoro, Indonesia); Mohamed Doheir (Universiti Teknikal Malaysia Melaka, Malaysia) pp. 337-342

Handwriting Ownership Recognition using Contrast Enhancement and LBP Feature Extraction based on KNN Nurul Diyah Ayu Partiningsih, Rizki Ramadhan Fratama, Christy Atika Sari, De Rosal Ignatius Moses Setiadi and Eko Hari Rachmawanto (Dian Nuswantoro University, Indonesia) pp. $343-347$

Comparison of HSV and LAB Color Spaces for Hydroponic Monitoring System Thomas Agung S and Setyo Aji Riwinanto (Politeknik Negeri Semarang, Indonesia); Suhendro S (Politeknik Negeri Semarang, Indonesia); Helmy Helmy and Arif Nursyahid (Politeknik Negeri Semarang, Indonesia); Ari Sriyanto Nugroho (Politeknik Negeri Semarang, Indonesia) pp. $348-353$

Automatic Docking Based on Visual Feedback on Remotely Operated Vehicle Muhammad Qomaruzzaman and Ronny Mardiyanto (Institut Teknologi Sepuluh Nopember, Indonesia) pp. $354-360$

Performance I mprovement of Human Activity Recognition based on Ensemble Empirical Mode Decomposition Enda Wista Sinuraya (Diponegoro University, Indonesia); Yosua Alvin Adi Soetrisno (Diponegoro University \& Faculty of Engineering, Indonesia); Denis Denis (Diponegoro University, Indonesia); Aminuddin Rizal (National Taiwan University of Science and Technology, Taiwan) pp. 361-366

Naive Bayes Classifier For Prediction Of Volcanic Status In Indonesia Firman Tempola (Universitas Khairun Ternate, Indonesia)
pp. 367-371

Case Based Reasoning For Determining The Feasibility Of Scholarship Grantees Using Case Adapatation Firman Tempola (Universitas Khairun Ternate, Indonesia) pp. $372-376$

A Development of Executive Information Based on Satisfaction Level of Students Eflita Yohana, Mochammad Facta, Karina Adhiriva and Awalina Sayekti (Diponegoro University, Indonesia) pp. $377-380$

Compressive Sensing Approach with Double Layer Soft Threshold for ECVT Static I maging Nur Afny Catur Andryani (Tanri Abeng University \& University of Indonesia, Indonesia); Dodi Sudiana and Dadang Gunawan (Universitas Indonesia, Indonesia)
pp. $381-386$

Context-based Hydrology Time Series Data for A Flood Prediction Model Using LSTM Indrastanti Ratna Widiasari (Satya Wacana Christian University \& Universitas Gadjah Mada, Indonesia) pp. 387-392 


\section{Energy Saving Measures and Potential of Energy Efficiency at the University of Surabaya, Based on EDGE Simulation}

\author{
Fitri Dwi Kartikasari \\ Dept. of Informatics Engineering \\ University of Surabaya \\ Surabaya, Indonesia \\ fitridk@staff.ubaya.ac.id
}

\author{
Elieser Tarigan \\ Dept. of Electrical Engineering \\ University of Surabaya \\ Surabaya, Indonesia \\ elieser@staff.ubaya.ac.id \\ Tuani Lidyawati \\ Dept. of Chemical Engineering \\ University of Surabaya \\ Surabaya, Indonesia \\ tuani@staff.ubaya.ac.id
}

\author{
Yunus Fransiscus \\ Dept. of Chemical Engineering \\ University of Surabaya \\ Surabaya, Indonesia \\ yunus@staff.ubaya.ac.id
}

\begin{abstract}
Higher education institutions play an essential role in promoting and developing sustainability. Implementation of energy efficient technology would reduce the amount of energy used significantly, in particular in buildings. The energy saving measures and potential for energy efficiency for a university campus are discussed and simulated in this paper. The simulation was done based on the parameters in EDGE (Excellence in Design for Greater Efficiency) simulation software. There are nine measures can be done without significant building renovation. Yet those changes still affect significantly to the energy efficiency if done simultaneously. The total energy savings that can be obtained by doing all those nine changes is $\mathbf{1 8 . 9 \%}$. This improvement will give operational carbon savings $769.78 \mathrm{tCO} /$ year.
\end{abstract}

Keywords-energy saving, energy measure, energy efficiency University of Surabaya

\section{INTRODUCTION}

Energy issue has been one of the primary issues, along with an environment, food, and population[1][2]. Energy consumption has increased at a rapid rate, by means of extracting and combusting of fossil fuels. This situation causes environmental problems, particularly related to the global warming and climate change [3][4][5]. Studies indicated that the implementation of energy efficient technology would reduce the amount of energy used significantly, in particular in buildings[6].

Implementation of energy efficiency plan would reduce energy consumption. There have been few studies of identifying the measures for energy saving. However, it is obviously seen that the potential to implement energy saving measures exists [3]. Many Attempts to seize the energy efficiency opportunity, accelerating the deployment energy saving measures have been made through: supporting innovation of energy efficiency; connecting technologies and knowledge on energy efficiency to finance feasible returns; harnessing the information on the power improvement of energy use of, driving its disclosure and availability; and encouraging action [7].

Higher education institutions such as universities, play an important role in promoting and developing sustainability. A university has the responsibility to integrate sustainable development into all its operations [1]. The University of Surabaya is one of the prime universities in the eastern area of Indonesia. From previous research it was revealed that, along with the development of the campus, the need for electrical energy in this university continues to increase every year. On the other hand, the results also detect a number of opportunities for electricity savings [8]. The management of the university has a high concern for energy saving issues. This study discusses the energy measures and simulates the energy savings potentials in the University of Surabaya (Ubaya) campus. The objective of the study is to find the most feasible way of energy efficiency. It is expected that the results from this study would be useful and applicable for scaling up to a wider scope energy efficiency.

\section{METHODS}

For the first step, an analysis of the current conditions is performed. Based on the number of active students and campus area, it can be calculated that the occupancy density is $3 \mathrm{~m}^{2} /$ student. Campus operational in accordance with the provisions is 8 hours per day, 5 working days per week, and about 60 national holidays per year. These data are used as inputs on the EDGE software to calculate the current conditions as the baseline.

Software to run this simulation study is so called EDGE (Excellence in Design for Greater Efficiency), provided by IFC, group of World Bank and open for public use. An account needs to be created (at the website : https://app/edgebuildings.com) [9] prior to full access and utilization of the system. The software enables to assist stakeholders in designing a resource efficient building. Several applicable parameters are included and can be simulated based on local condition resulting in measurable and comparable resource utilization for buildings.

This software has three components representing the resource used in a building; those are energy, water and material components. The system is able to calculate the amount of resource used in a building, and by simulating several parameters, comparison of several options can be 
made. Thus, the utility saving can be described. Moreover, EDGE software also able to measure reduced carbon footprint following the utility saving pattern. However, in this study simulation study was conducted with a focus on energy measures for all building in the campus area. Detail information regards to the energy utilization has been collected and used to run the software. Some parameters (system/solution) in the program had been chosen based on the current condition in the University and simulated in order to find the most feasible option for energy efficiency scenario.

\section{RESULTS AND DISCUSSIONS}

The object of this simulation study is all buildings in the campus area of the University of Surabaya, which is located in Jalan Raya Tenggilis, Surabaya, East Java. With a total area of nearly 14 hectares, there are 29 permanent buildings for various functions such as classroom, laboratory, library, administration office, and cafeteria. All buildings are typically constructed from brick and plaster, but differ in number of storey. The abbreviations is used for building names, represent the name of each building; the first letter describes the name of faculty in which the building belongs to, for example, $\mathrm{P}$ for Psychology, E for Economic, and T for
Indonesia) and so on. This abbreviation system is not applied for common purpose building (eg. International Village, Library, Canteen/Cafeteria). Typical building is as shown in Figure 1., meanwhile the number of storey in each building that is included in this study is provided in Table 1 [10].

Electricity for all buildings is supplied by National Electricity company (PLN) and used mainly for lighting and cooling purposes. For lighting, all building use fluorescent (FL) type of lamp; as for cooling most of building use noncentralized cooling system - only library building uses centralized system. Electricity is turned on during working hours, $08.00-17.00$, except for Library, which is operated $08.00-19.00$ daily.

With the current campus condition applying 5 working days with a total of 40 working hours per week and the occupancy density is $3 \mathrm{~m} 2$ /person, it appears that the largest energy absorption is used for air conditioning systems. This condition is used as a base case in this study. This base case is generated from the software by entering the basic parameters that correspond to the real conditions. Furthermore from the base case will be simulated changes that can be made according to EDGE measurement indicators to estimate energy efficiency.

The simulation results from EDGE software are shown in Table 2. It shows the codes, the referred measures, and

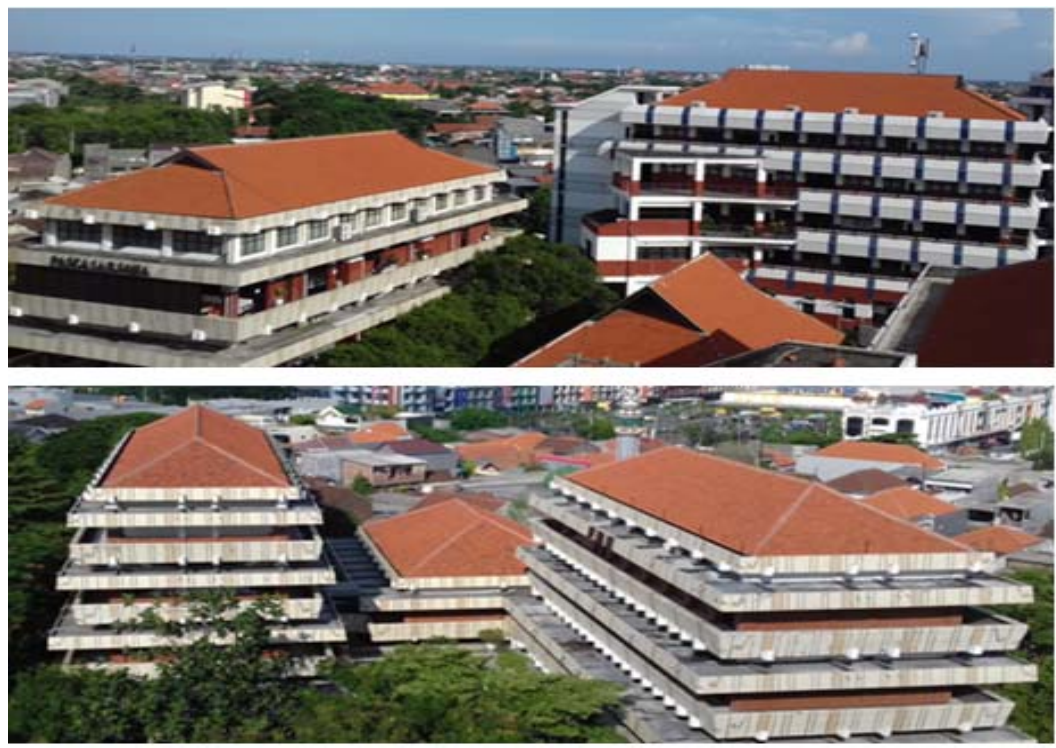

FIG. 1. Typical Building of University of Surabaya

TABle 1. Storey BuILding AT UNIVERSity of SuRABAyA

\begin{tabular}{|c|c|}
\hline Storey Building & Buildings \\
\hline Two-storey & $\begin{array}{c}\text { EB, FA, TA, PA, International } \\
\text { Village, Canteen }\end{array}$ \\
\hline Three-storey & TB,ED \\
\hline Four-storey & EA, EC, FB, FC, FD, \\
& FE,HA,HB,TC, TD, TE, TF,PB, \\
& PC, PD, PE \\
\hline Six-storey & FF, FG, Library, TG \\
\hline
\end{tabular}

Engineering (Teknik in Bahasa Indonesia). Therefore TA refers to building A of Faculty of Engineering, FA refers to building A of Faculty of Pharmacy (Farmasi in Bahasa energy savings gained when applying the corresponding measures. There are 2 measures that give an energy efficiency impact of more than 10\%, i.e. EDE05 and EDE10. EDE05 requires a significant reshuffle on the roof of every building. Meanwhile EDE10 will affect the comfort of indoor activities. Therefore those two measures are not recommended.

There are several measures that can be done without significant building renovation. Yet those changes still affect significantly to the energy efficiency if done simultaneously. Those are the use of reflective paint on the roof and walls (EDE02 and EDE03), the addition of external shading devices (EDE04), the use of energy-efficient bulbs 
in all campuses areas (EDE23 and EDE24), occupancy sensors in all indoor areas (EDE25, EDE26 and EDE27), and photoelectric sensors to harvest daylight (EDE28). EDE02 and EDE03 together will provide an energy saving impact of $6.6 \%$. EDE04 contributes 3\% energy savings. Use of energy-saving lamps will save energy by $2.9 \%$. While the overall use of the sensor will save energy by $9.3 \%$. The total energy savings that can be obtained by doing all those nine changes is $18.9 \%$. This figure is very close to the standard set by EDGE of $20 \%$. The comparison between the base case and improved case are shown in figure 2 . The improved case is the one that applies all those nine measures which give $18.9 \%$ energy efficiency. In this case, it will save energy around $280 \mathrm{MWh} /$ year. Since the current electricity demand is fully obtained from the state power company whose majority of the energy source is still from fossil fuel, this efficiency will also contribute to reducing $\mathrm{CO}_{2}$ emissions. Assuming a reduction in emissions of 0.6 $\mathrm{kg} . \mathrm{CO}_{2} / \mathrm{kWh}$, these improvements will give operational carbon savings about $769.78 \mathrm{tCO} 2 /$ year.

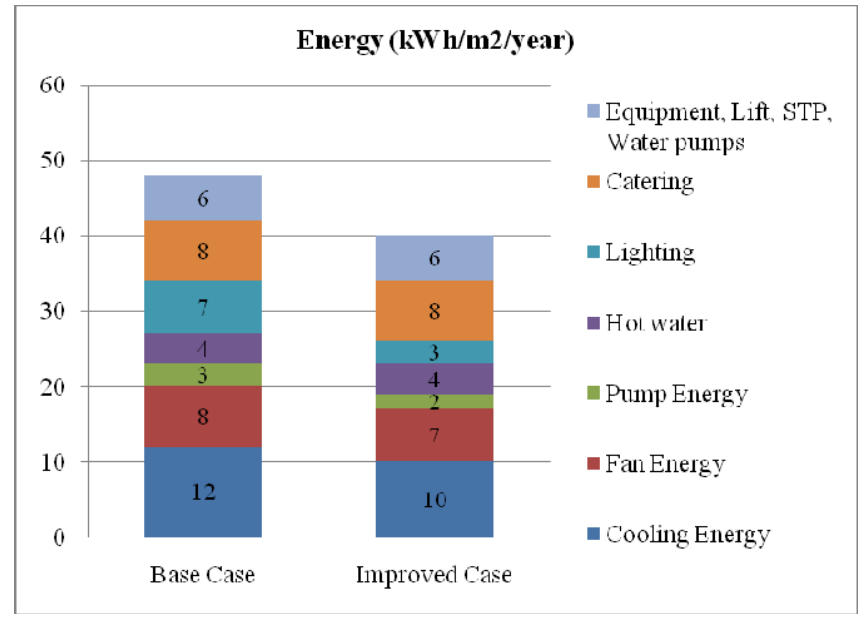

FIG. 2. Energy Saving Comparison between Based Case and Improved Case

Table 2. Simulation Result of All Energy SaVing Measures

\begin{tabular}{|c|c|c|}
\hline Code & Measure & Energy Saving (\%) \\
\hline EDE01 & Reduced Window To Wall Ratio & 3.1 \\
\hline EDE02 & Reflective Paint/Tiles For Roof & 6.1 \\
\hline EDE03 & Reflective Paint For External Walls & 0.5 \\
\hline EDE04 & External Shading Devices & 3 \\
\hline EDE05 & Insulation Of Roof & 13 \\
\hline EDE06 & Insulation Of External Walls & 1.7 \\
\hline EDE07 & Low-E Coated Glass & 1.7 \\
\hline EDE08 & Natural Ventilation For Corridors & 0.9 \\
\hline EDE09 & Natural Ventilation For Classrooms & 0 \\
\hline EDE10 & Ceiling Fans In All Classrooms & 15.8 \\
\hline EDE11 & Variable Refrigerant Volume (Vrv) Cooling System & -7.9 \\
\hline EDE12 & Air Conditioning With Air Cooled Chiller & -13.1 \\
\hline EDE13 & Air Conditioning With Water Cooled Chiller & 2.1 \\
\hline EDE14 & Ground Source Heat Pump & -8.1 \\
\hline EDE15 & Absorption Chiller Powered By Waste Heat & 7.2 \\
\hline EDE16 & Recovery Of Waste Heat From The Generator For Space Heating & 0 \\
\hline EDE17 & Variable Speed Drives On The Fans On Cooling Towers & 0.8 \\
\hline EDE18 & VARIABLE SPEED DRIVES IN Ahus & 0 \\
\hline EDE19 & Variable Speed Drive Pumps & -0.5 \\
\hline EDE20 & Sensible Heat Recovery From Exhaust Air & 7.4 \\
\hline EDE21 & High Efficiency Condensing Boiler For Space Heating & 0 \\
\hline EDE22 & High Efficiency Boiler For Water Heating & 0 \\
\hline EDE23 & Energy Saving Light Bulbs For Internal Spaces & 1.9 \\
\hline EDE24 & Energy Saving Light Bulbs For External Areas & 1 \\
\hline EDE25 & Occupancy Sensors In Bathrooms & 0.3 \\
\hline EDE26 & Occupancy Sensors In Classrooms & 5.4 \\
\hline EDE27 & Occupancy Sensors In Corridors & 0.2 \\
\hline EDE28 & Photoelectric Sensors To Harvest Daylight & 3.4 \\
\hline EDE29 & Solar Hot Water Collectors & 4.7 \\
\hline EDE30 & Solar Photovoltaics & $\begin{array}{c}\text { Depend on the annual } \\
\text { electricity gained }\end{array}$ \\
\hline EDE31 & Other Renewable Energy For Electricity Generation & $\begin{array}{c}\text { Depend on the annual } \\
\text { electricity gained }\end{array}$ \\
\hline
\end{tabular}




\section{CONCLUSION}

The simulation studies show that by applying the combination of nine measures of 31 measures of energy saving in the simulation would result in the total energy efficiency of $19 \%$ for buildings of the University of Surabaya. The measures refer respectively to: the use of reflective paint on the roof and walls, the addition of external shading devices, the use of energy-efficient bulbs in all campuses areas, occupancy sensors in all indoor areas, and photoelectric sensors to harvest daylight. The implementation of the measures will give operational carbon savings 769.78 tCO2/year. However, energy efficiency for existing building could be attempted by many ways.

\section{REFERENCES}

[1] E. Tarigan, "Energy Saving Measures and Simulation in the Library Building of University of Surabaya," J. Teknol. Rekayasa, vol. 3, no. 1, pp. 63-70, 2018.

[2] N. Ito, "How much FEE we can pay for sustainable society building," Int. J. Adv. Sci. Eng. Inf. Technol., vol. 6, no. 3, pp. 295-301, 2016

[3] Y. Geng, K. Liu, B. Xue, and T. Fujita, "Creating a 'green university' in China: A case of Shenyang University," J. Clean. Prod., vol. 61, pp. 13-19, 2013.
[4] G. Ho, S. Dallas, M. Anda, and K. Mathew, "Renewable energy in the context of environmentally sound technologies - training and research programmes at the Environmental Technology Centre, Murdoch University," Renew. Energy, vol. 22, no. 1, pp. 105-112, 2001.

[5] R. L. Hwang, T. P. Lin, and N. J. Kuo, "Field experiments on thermal comfort in campus classrooms in Taiwan," Energy Build., vol. 38, no. 1, pp. 53-62, 2006

[6] B. Patel and P. Patel, "Sustainable campus of Claris lifesciences through green initiatives," Renew. Sustain. Energy Rev., vol. 16, no. 7, pp. 4901-4907, 2012.

[7] Department of Energy and Climate Change, "The Energy Efficiency Strategy: The Energy Efficiency Opportunity in the UK," Report, no. November, p. 30 pp., 2012.

[8] E. Tarigan, F. D. Kartikasari, and Djuwari, "Study on the Energy Efficiency Strategies and Feasibility of the Use of Renewable Energy at University of Surabaya," 2016.

[9] Ifc.org, "Why EDGE," 2016. [Online]. Available: http://www.ifc.org/wps/wcm/connect/Topics_Ext_Content/IFC_ External_Corporate_Site/EDGE/Why+Edge/. [Accessed: 20-Jun2016].

[10] E. Tarigan, "Simulation and Feasibility Studies of Rooftop PV System for University Campus Buildings in Surabaya , Indonesia," vol. 8, no. 2, 2018. 